\title{
A standard radon-222 source for the system of high-accuracy monitoring of radon-hazardous facilities in Ukraine
}

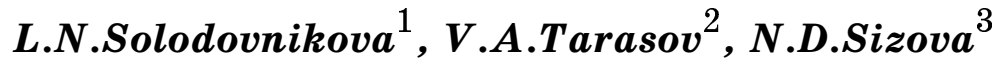 \\ ${ }^{1}$ PSI "Science and Technology Cluster "Institute for Single Crystals", \\ National Academy of Sciences of Ukraine, \\ 60 Nauky Ave., 61072 Kharkiv, Ukraine \\ ${ }^{2}$ Institute for Scintillation Materials, STC "Institute for Single Crystals", \\ National Academy of Sciences of Ukraine, \\ 60 Nauki Ave., 61072 Kharkiv, Ukraine \\ ${ }^{3}$ Kharkiv National Construction and Architecture University, \\ 40 Sumska Str., 61002 Kharkiv, Ukraine
}

Received January 9, 2017

This scientific paper describes the creation procedure and use of the radon-222 generator based on uranium ore. The research done resulted in selection of an optimal uranium ore composition. Based on temperature field computations we selected the uranium ore capsule material. A standard source structure has been suggested. Optimal options of the use of uranium ore specimens for the generator, volumetric activity standard and also for the device calibration were specified. The monitoring of some real radon-hazardous facilities, using the devices calibrated by standard radon-222 sources, showed a considerable overstepping of the volumetric activity of radon-222 in comparison with available standards.

Keywords: uranium, radon generator, volumetric activity radon standard.

Описывается процедура создания и использования генератора радона-222 на основе урановой руды. В результате исследований выбран оптимальный состав урановой руды. На основе расчетов температурного поля выбран материал капсулы урановой руды. Предложена конструкция стандартного источника. Предложены оптимальные варианты использования образцов урановой руды для генератора, стандарта объемной активности, а также для калибровки устройства. Мониторинг некоторых реальных радоноопасных объектов с использованием устройств, откалиброванных по стандартным источникам радона-222, показал значительное превышение объемной активности радона-222 по сравнению с имеющимися нормами.

Стандартне джерело радіоактивного радону-222 для системи високоточного моніторингу небезпечних для радону об'єктів в Україні. Л.Н.Солодовнікова, В.О.Тарасов, Н.Д.Сизова.

Описано процедуру створення та використання генератора радону-222 на основі уранової руди. Проведене дослідження забезпечило вибір оптимального складу уранової руди. Виходячи з обчислень температурного поля, обрано матеріал капсули уранової руди. Запропоновано конструкцію стандартного джерела. Запропоновано оптимальні варіанти використання зразків уранової руди для генератора, стандарта об'ємної активності, а також для калібрування пристрою. Моніторинг деяких реальних радононебезпечних об'єктів за допомогою приладів, каліброваних зі стандартними джерелами радону-222, показав значне перевищення об'ємної активності радону- 222 у порівнянні з наявними нормами. 


\section{Introduction}

It is known that the radioactive radon222 gas and the fission products of it make a dominating contribution (about $60 \%$ ) to the collective dose of radiation of the population in Ukraine that exceeds $2700 \mu \mathrm{Sv} /$ year [1]. The territory of Ukraine has strong radon sources, in particular uranium ore and coal fields, the storages for the industrial waste sources of ionizing radiation, and the anthropogenically-intensified sources of a natural origin. In this connection, a high-accuracy monitoring of radon-222 is considered to be a national problem in Ukraine [2-5].

The most important components of a high-accuracy monitoring of radon-222 are measuring devices, control methods and standard sources. Radon-222 volumetric activity standard sources need the radon sources, i.e. the generators. These should be stable and safe and be able to generate radon-222 with the volumetric activity reproduction ranging from 1 to $5 \cdot 10^{4} \mathrm{~Bq} / \mathrm{m}^{3}$.

The references describe different radon generator options, in particular liquid generators, film generators and solid-state generators. For example, national radon-222 volumetric activity standards in the USA [6], England [7], Germany [8], etc. [9-11] include standard radium-226 salts-based radon-222 liquid generators that are metrologically related to radium-226 mass standards [12]. France [13] suggested the radon-222 source formed by the galette made of porous material with the radium226 deposited on it. To provide the radon222 emanation stability the galette is blasted by gas of a high humidity (90 to $95 \%)$. Russia [14] suggests the method that consists in dissolution of the radium salt in the carrier material that can be represented by low-melting salt mixtures of alkali metals and alkaline earth metals, and it also consists in the solid-state radon accumulation and the liberation of it when the carrier material is melted.

The reference data analysis showed that liquid, film and solid-state radon-222 sources used in practice by many countries of the world fail to meet many requirements set to the standard radon-222 source developed in Ukraine. The selected material and source construction must provide a lowbackgrounding, the radiation safety and usability of the radon-222 source.

The paper [15] suggests an option for radon-222 generators based on uranium ore.
This scientific paper analyzes the properties of a suggested radon-222 generator based on uranium ore. It also defines optimal options for the use of this material for the generator, for the volumetric activity standard and for the device calibration. The radon-222 concentration measurement data are discussed for real radon hazardous facilities using the devices calibrated by standard radon-222 sources.

\section{Experimental}

Standard iron ore specimens were selected taking into consideration their composition and dispersion, based on the research data and the analysis of the certificates of uranium ore specimens issued by the State Company "Kirovgeology". The research methods are based on comparison of the mass fractions of uranium and radium in specimens under investigation and reference specimens (NSS). Storage conditions of the NSS provide the stability of its characteristics and correspond to the Standard Specimen Certificate for the UR-768C No483-74 specimen.

The NSS chemical composition stability was assessed by the experts from the NGC "Kirovgeology" according to the industry standard (IS) 41-08-252-85 [16].

Uranium mass particles contained in the NSS were measured using the X-ray spectral method and the X-ray fluorescent analyzer XFA-6.

Radium-226 was measured using the UIP-1 device according to the instruction recommended by the Mingeo of the USSR [17].

A major characteristic of the radon sources (standard uranium ore specimens), i.e. the emanation capacity was defined using the liquid scintillation spectrometer Quantilus-1220 manufactured by the Wallac Company (Finland). The nine samples were prepared for the measurement and the measuring technique was selected in compliance with the in-line documentation provided for the alpha beta spectrometric system Quantilus-1220.

To develop the radon generator structure the source geometry, the capsule material and the temperature mode of generator operation were optimized. The computations done allowed for the optimal choice. The estimates of temperature fields and radon concentrations were done using the method of R-functions [18].

A volumetric concentration of radon in the enclosed space atmosphere and at out- 
Table 1. Determination data of uranium and radium contents in standard uranium ore specimens and mathematical processing data

\begin{tabular}{|c|c|c|c|c|c|c|c|c|c|}
\hline \multirow{2}{*}{$\begin{array}{l}\text { A type of the } \\
\text { NSS, NSS } \\
\mathrm{N}^{\mathrm{O}} \text { according } \\
\text { to the register }\end{array}$} & \multirow[t]{2}{*}{ Element } & \multirow{2}{*}{$\begin{array}{c}\text { Attested } \\
\text { mass. } \\
\text { fraction, } \\
10-3 \%\end{array}$} & \multirow[t]{2}{*}{$\begin{array}{l}\text { Attestation } \\
\text { error } 10-3 \%\end{array}$} & \multicolumn{2}{|c|}{$\begin{array}{c}\text { Analysis data } \\
10-3 \%\end{array}$} & \multirow[t]{2}{*}{$\begin{array}{c}d^{*} \\
10-3 \%\end{array}$} & \multirow[t]{2}{*}{$\begin{array}{c}S d^{*} \\
10-3 \%\end{array}$} & \multicolumn{2}{|c|}{$\begin{array}{c}t-\text { the Student } \\
\text { criterion }\end{array}$} \\
\hline & & & & $\mathrm{C}-1^{*}$ & $\mathrm{C}-2^{*}$ & & & Operating & Table \\
\hline UR-47S & uranium & 47 & 1 & 47.1 & 47.0 & 0.1 & 1.3 & 0.3 & 2.09 \\
\hline $480-74$ & radium & 49 & 1 & 48.9 & 49.0 & -0.1 & 1.1 & 0.4 & 2.09 \\
\hline UR-114S & uranium & 114 & 2 & 113.6 & 114.4 & -0.8 & 2.2 & 1.6 & 2.09 \\
\hline $481-47$ & radium & 115 & 1 & 115.2 & 114.9 & 0.3 & 1.8 & 0.8 & 2.09 \\
\hline UR-240S & uranium & 240 & 4 & 240.4 & 239.0 & 0.9 & 3.8 & 1.1 & 2.09 \\
\hline $482-74$ & radium & 238 & 12 & 238.2 & 230.4 & -0.2 & 2.5 & 0.4 & 2.09 \\
\hline UR-768S & uranium & 768 & 11 & 766.8 & 768.4 & -1.6 & 11.7 & 0.6 & 2.09 \\
\hline 483-74 & radium & 762 & 15 & 761.9 & 761.1 & 0.8 & 4.8 & 0.2 & 2.09 \\
\hline
\end{tabular}

$\mathrm{C}-1^{*}$ is an average contribution of the defined element to the NSS that is subject to the verification; $\mathrm{C}-2^{*}$ is an average contribution of the defined element to the NSS used for the comparison; $d^{*}$ is an average difference of analysis data for each sample; $S d^{*}$ is the analysis data difference dispersion.

door sites was measured using several devices, in particular the radon-monitor $\mathrm{Al}$ phaGUARD PQ2000 with the radon-222 volumetric activity measurement range of 2 to $2 \cdot 10^{6} \mathrm{~Bq} / \mathrm{m}^{3}$; the radiometer $\mathrm{RGA-09}$ with the radon-222 volumetric activity measurement range of 50 to $1 \cdot 10^{4} \mathrm{NBq} / \mathrm{m}^{3}$; the inert gas and aerosol activity control unit RAM-31 manufactured by the RADOS Company with the radon-222 volumetric activity measurement range of 10 to $1 \cdot 10^{4} \mathrm{~Bq} / \mathrm{m}^{3}$. These tools of the measuring technique were verified using a special DETU 12-01-97 unit [19] according to the DSTU 3536-97 standard [20].

\section{Results and discussion}

Standard UR-47C, UR-114C, UR-240C and UR-768C specimens were studied to select the specimens for the developed radon222 source proceeding from the composition stability, dispersion, and uranium and radium contents and to provide their governmental certification for the period of 1995 to 2025 according to [21].

To study each type of the NSS, the ten NSS specimens of an ordinary storage and ten check specimens were provided for the research. Two samples of each NSS specimen were selected for the analysis and later on these were analyzed as individual samples. An entire batch of the samples (20 test samples and 20 check samples of each type of the NSS) was analyzed in one gulp in the next order: first the NSS sample that is the subject to the verification, and then the NSS reference sample, etc.

A content of uranium and radium in standard uranium ore specimens and mathematical processing data are given in Table 1.

Based on the data given in the Table 1 we have the following:

Average values of the mass fractions of uranium and radium in UR-47S, UR-114S, UR-240S and UR-768S specimens correspond to those given in the certificates within the error of estimate.

According to the Student criterion, average values of the difference between the content of radium in compared UR-47S, UR-114S, UR-240S and UR-768S specimens are close to zero.

Based on the research data obtained for uranium ore specimens as for the composition stability, dispersion, and uranium and radium content the UR-786S specimen with the highest content of uranium-238 and radium-226 was selected to create the radon222 source. Additional research of the standard UR-768S specimen was done by the State Science and Industry Organization "Metrology" [22].

To define a specific emanation of radon222 the nine packages of original standard UR-768 specimen were subjected to experimental investigations.

One sample with the mass of 1 gram of the total amount was taken from each package. As a result we had nine samples only. All the samples were put into Teflon cuvettes. Specific radon activity in the samples 


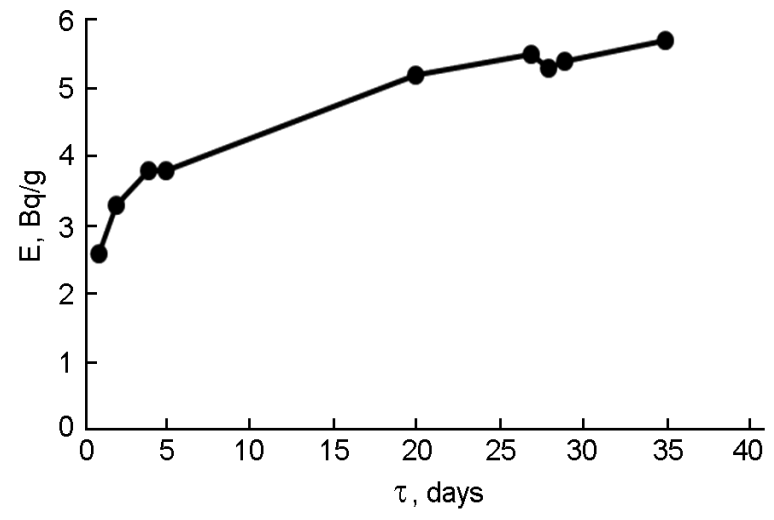

Fig. 1. Averaged relationship of the specific emanation of radon-222 as a function of time.

was measured with the alpha beta spectrometric system Quantilus-1220 after prolonged exposure to cuvettes. Obtained average value for measurement data of radon222 specific emanation are expressed as:

$$
E_{Q}=(5.52 \pm 0.57) B q / g \text {, at } P=0.99 \text {. }
$$

However, according to the certificate No. 483-74 of the same sample UR-768C, the value of the specific emanation is less than obtained value $E_{S}=4.79 \pm 0.72 \mathrm{~Bq} / \mathrm{g}$ at $P=0.9$ ).

More detailed studies of the accumulation of radon in the samples, obtained using the alpha beta spectrometric system Quantilus-1220, made it possible to explain this difference.

Figure 1 gives the change in the specific activity of radon in the sample with time.

Figure 1 shows that the specific activity of radon, equal to $4.8 \mathrm{~Bq} / \mathrm{g}$, is achieved after 15 days of exposure of the sample. The value of specific activity approaches $5.2 \mathrm{~Bq} / \mathrm{g}$ after 30 days of exposure. The value of $5.5 \mathrm{~Bq} / \mathrm{g}$ can be achieved with a much longer exposure time. This value can be taken as the equilibrium value of the specific activity of radon-222.

Using the uranium ore UR-768C specimen we created the three identical reference generators of radon-222, in particular GRT1E, GRT-2E and GRT-3E, each with a specified mass of the standard specimen to reproduce the volumetric activity of radon222 in the standard specimen in the range of 1 to $5 \cdot 10^{4} \mathrm{~Bq} / \mathrm{m}^{3}$. When developing the radon-222 generator the mass of standard UR-768S specimen required for the generation of radon-222 in the amount of 1 to $1 \cdot 10^{4} \mathrm{~Bq}[22]$ was defined for each of them.

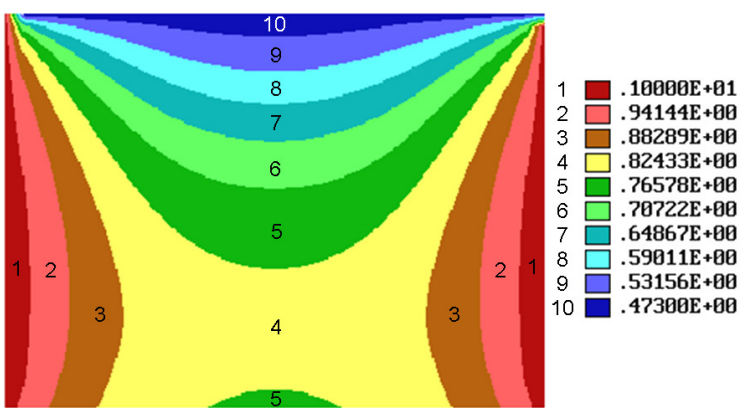

a)

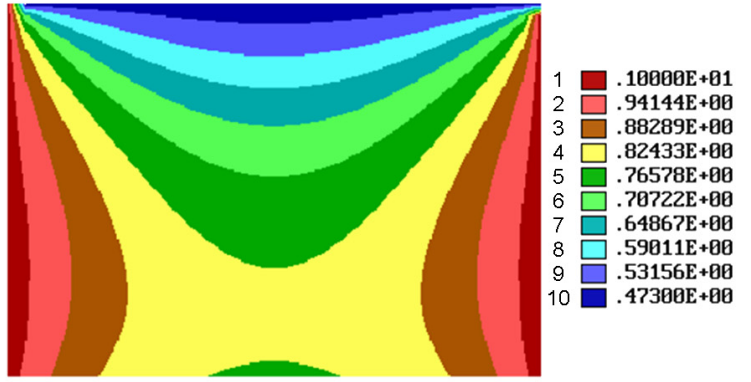

b)

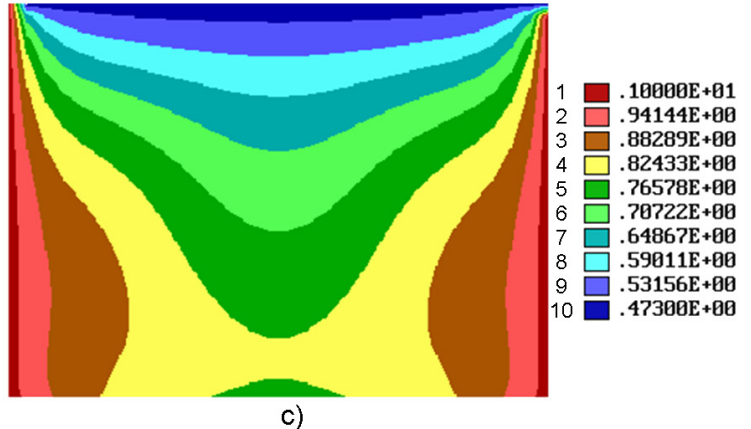

Fig. 2. Temperature field level lines for the materials of capsule wall made of stainless steel (Fig. 2a), titanium (Fig. 2b) and tungsten (Fig. 2c).

$$
M=\frac{A}{E_{S}}=\frac{1 \cdot 10^{4} B q}{5.52 B q}=1923 g
$$

When developing the reference source the capsule volume was calculated to place the required mass of standard UR-768 specimen into it. The capsule material was selected based on the research data of the distribution of temperature field in the standard specimen exposed to the heating in the capsules made of a different material, using the method of R-functions [18].

Table 2 gives physical characteristics of the materials used for the experimental specimens of the capsules that are used for the placement of the standard specimen of uranium ore UR-768C in the reference source, where $\rho$ and $c$ are the material density and the specific heat capacity of it, accordingly, and $\lambda$ is the heat emission coef- 
L.N.Solodovnikova et al. / A standard radon-222 ...

Table 2. Physical parameters of the capsule of a reference radon-222 source

\begin{tabular}{|c|c|c|c|c||}
\hline \hline & $\begin{array}{c}\text { Stainless steel } \\
12 \text { X18H10T }\end{array}$ & $\begin{array}{c}\text { Titanium WT-4, } \\
\text { WT-6 }\end{array}$ & Tungsten & $\begin{array}{c}\text { UR-768S } \\
\text { (standard uranium } \\
\text { ore specimen) }\end{array}$ \\
\hline$\lambda$ & $15 \mathrm{~W} / \mathrm{m} \cdot \mathrm{K}$ & $22 \mathrm{~W} / \mathrm{m} \cdot \mathrm{K}$ & $179 \mathrm{~W} / \mathrm{m} \cdot \mathrm{K}$ & $17 \mathrm{~W} / \mathrm{m} \cdot \mathrm{K}$ \\
$c$ & $460 \mathrm{~J} / \mathrm{kg} \cdot \mathrm{K}$ & $520-522 \mathrm{~J} / \mathrm{kg} \cdot \mathrm{K}$ & $134 \mathrm{~J} / \mathrm{kg} \cdot \mathrm{K}$ & $116 \mathrm{~J} / \mathrm{kg} \cdot \mathrm{K}$ \\
$\rho$ & $7.9 \mathrm{~kg} / \mathrm{m}^{3}$ & $4.5 \mathrm{~kg} / \mathrm{m}^{3}$ & $19.3 \mathrm{~kg} / \mathrm{m}^{3}$ & $12 \mathrm{~kg} / \mathrm{m}^{3}$ \\
\hline
\end{tabular}

ficient of the material of which the capsule is made.

All geometric parameters of the capsule of the reference source of radon-222 except for one were invariable. Only one parameter $B$, the capsule wall thickness was varying in the range of 5 to $30 \mathrm{~mm}$. A coefficient $\lambda$ of heat emission from the powder surface of a standard specimen of uranium ore UR-768S was also varying in the range of $8 \mathrm{~W} / \mathrm{m}^{2} \cdot \operatorname{deg}$ to $12 \mathrm{~W} / \mathrm{m}^{2} \cdot \operatorname{deg}$.

Fig. 2(a,b,c) gives the patterns of level lines of the temperature field at constant geometric parameters of the capsule for the three materials whose physical characteristics are given in Table 1 at heat emission coefficient $\lambda$ values equal to $8 \mathrm{~W} / \mathrm{m}^{2} \cdot \mathrm{deg}$. Qualitatively, the patterns of level lines of the temperature field resemble those for the materials of capsule wall made of stainless steel (Fig. 2a) and titanium (Fig. 2b). If tungsten is used as a capsule wall material (Fig. 2b) the pattern of level lines of the temperature field shows an apparent rise of temperature in the middle of the reference source of radon-222.

It should be noted that the zone of heat distribution in the temperature field gives an opportunity to trace the character of its penetration into the capsule. For example, the comparison of temperature values in the green color gamma shows that the temperature zone occupies a larger area for the capsule made of tungsten in comparison with the capsules made of stainless steel and titanium.

Analogous temperature field research data were obtained for heat emission coefficient $\lambda$ values equal to $10 \mathrm{~W} / \mathrm{m}^{2} \cdot \mathrm{deg}$ and $12 \mathrm{~W} / \mathrm{m}^{2} \cdot \mathrm{deg}$ for the same three capsule materials [18].

The heating of experimental capsules (Fig. 2a, b, c) made of stainless steel, grade 12C18N10T, titanium grade WT-4 (WT-6) and tungsten showed that the capsule made of stainless steel, grade $12 \mathrm{X} 18 \mathrm{H} 10 \mathrm{~T}$ possesses all physical characteristics required for the maintenance of optimal temperature mode for the emanation of radon-222 by the reference source. It provides the achievement of an optimal temperature mode to stabilize a constant value of the emanation coefficient of radon-222 that is the major metrological performance of the reference source of radon. Hence, the calculated analysis of temperature fields in the capsule with the standard uranium ore specimen enabled the selection of appropriate capsule material and the source structure, i.e. the radon generator. Fig. 3 gives the developed reference source structure, in particular that of the radon-222 generator.

The reference source includes the casing made of stainless steel 1 that houses the capsule 2 with the uranium ore 2 enclosed by the radon-222 filter 4 and the lead shield 5 . The capsule 2 is encircled by the heater 6 and it is surrounded by the dielectric hollow cylinder 7 with the lead shield 8 . The storage chamber 9 of incoming radon 10 is arranged over the radon filter 4 . It is closed by the cover 11 equipped with the inlet valve 12 and the outlet valve 13 . The temperature sensor 14 that is arranged over the storage chamber 9 and is fixed to the lead shield 8 and the heater 6 are connected to the temperature control unit 15. A system of the filtration of atmospheric air 16 required for the displacement of radon-222 from the storage chamber 9 to the measuring chamber 17 connected to the outlet valve 13 is connected to the inlet valve 12 . A vacuum in the measuring chamber 17 is achieved using the vacuum pump 18 and the vacuum meter 19 .

The radon generation procedure is as follows. The radon-222 source with the uranium ore 3 is connected to the temperature control unit 15 that maintains a constant temperature in the capsule 2 with uranium ore 3 and accurately measures an average value of the temperature of uranium ore 3 . The radon-222 source is matured for 30 days to create the radiation equilibrium inside the uranium ore $3-$ radon 10 system. The purified air that ousts the gener- 


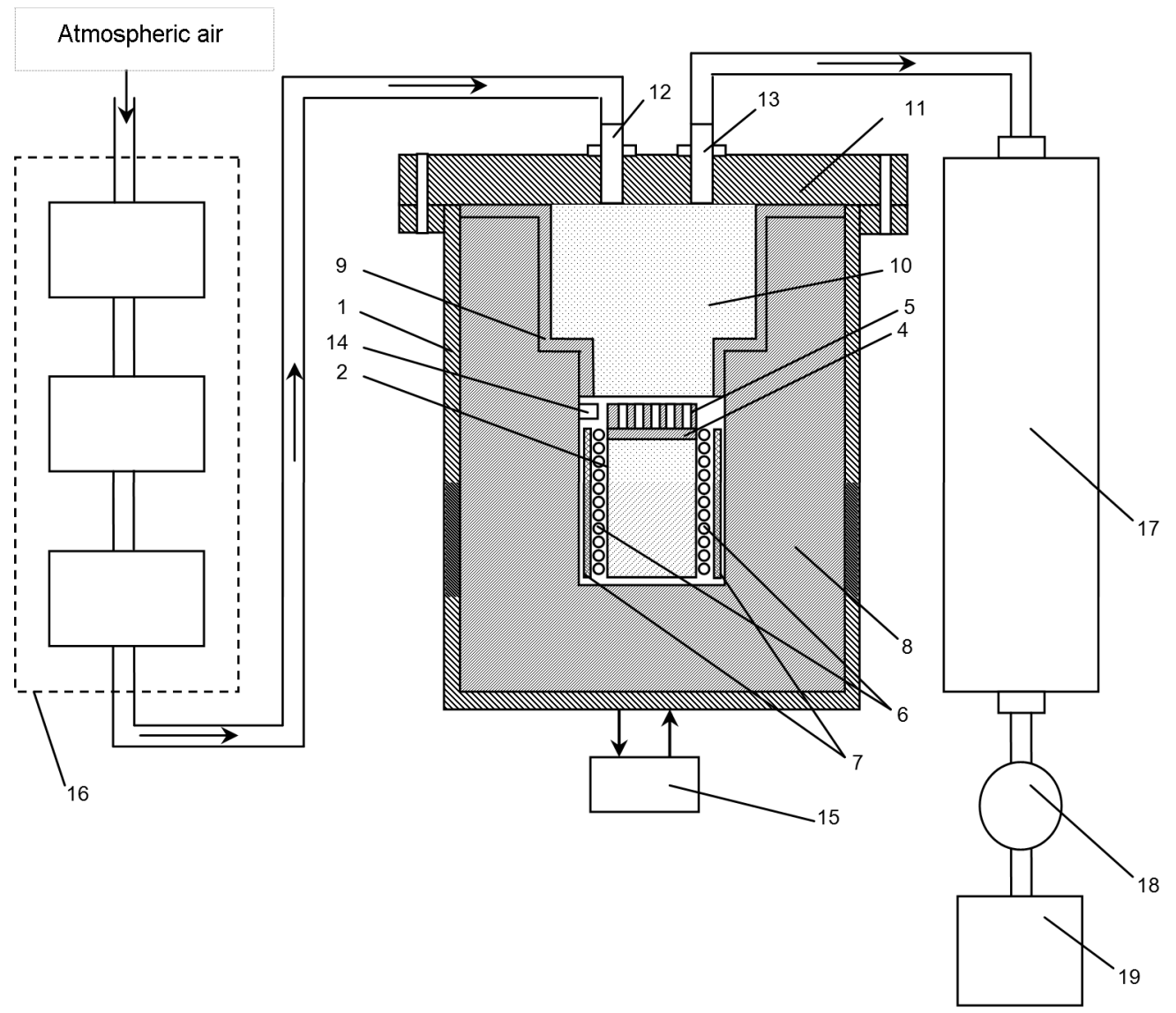

Fig. 3. Reference radon-222 source structure

ated radon 10 is supplied under pressure to the storage chamber 9 through the inlet valve 12 [15].

Developed radon-222 sources were used for the periodic calibration and control of metrological performances of the measuring tools of the volumetric activity of radon222 straight at monitored radon hazardous facilities, in particular Kharkiv SpecialPurpose Center UKR State Association "Radon" of the Ministry of Emergency Situations, former Soviet Union nuclear weapon waste repository "Makarov Facility", the "Ukrytie" Facility, State Special-Purpose Enterprise Chernobyl Nuclear Power Plant and the Section II of Sukhachevsky tailing nuclear waste storage facility of the former PA "Predneper Chemical Plant" [23-26]. The monitoring showed a considerable overstepping of the volumetric activity of radon-222 in comparison with available standards [27].

\section{Conclusions}

This scientific paper describes the comprehensive research of the material used for the reference source and the generator structure with the prediction of temperature fields for the radon source, calibration of the devices and the monitoring of radon hazardous facilities. In the course of work an optimal uranium ore composition was selected. Based on the computations of temperature fields the capsule material was also selected and the reference source structure was suggested. Using the reference source, the measuring tools of the volumetric activity of radon-222 were calibrated to ensure a high-accuracy monitoring. The monitoring data showed a considerable exceeding of the radon content in the air of monitored facilities.

Hence, the created reference source of radon provided an operation of a primary standard of the volumetric activity of radon-222; it gave an opportunity to calibrate the measuring tools of the volumetric 
activity of radon and provide a high-accuracy monitoring of the volumetric activity of radon at different radon-hazardous facilities.

\section{References}

1. Sources, Effects and Danger of Ionizing Radiation, NK DAR UN Report for 1988. Mir, Moscow (1992), v.1 [in Russian].

2. Sources, Effects and Danger of Ionizing Radiation, Report of the UN Scientific Committee on the Effects of Atomic Radiation to the General Assembly for 2000, Mir, Moscow (2002) [in Russian].

3. A.N.Letuchii, V.I.Ryabukhin, I.P.Pinchuk, ANRI, 5, 31 (1996/97).

4. A.Ya.Yafasova, Ecological Herald, Tashkent, Uzbekistan, 5-6, 34 (2001).

5. A.K.Guskova, A.V.Barabanova, A.E.Baranov et al., Sources, Effects and Danger of Ionizing Radiation, Report of the NK DAR 1988, Mir, Moscow (1993), v.2, p.655 [in Russian].

6. R.Colle, J.M.R.Hutchinson, M.R.Unterweger, J.Res. Natl.Inst. Stand. Technol., 95, 155 (1990).

7. National Measurement Standards and Calibration Facilities for the United Kingdom, NPL, London (1995).

8. A.Honig, A.Paul, S.Rottger, U.Keyser, Nucl. Instrum. and Meth. Phys. Res., 416, 252 (1998).

9. A Reference Book, ed. by V.Tarbeev, VNIIM, Leningrad, (1997) [in Russian].

10. Yu.V.Kuznetsov, S.A.Medvedeva, C.G.Rostukov, Collection of Scientific Papers, ed. by V.I.Fominykh, Energoatomizdat, Leningrad (1989) [in Russian].

11. F.Gavlik, M.Dyurchik, D.Nikomedova et al., ANRI, 1, 36 (1995).

12. O.Honigschmid, Akad.Wiss Wien., 8, 30 (1945).

13. France Patent 2.660.105 (1990).

14. Author's certificate USSR, 1568782 (1995).

15. L.N.Yakovleva, M.I.Kravchenko, Ukr. Metrolog. J., 1, 53 (1999).
16. IS 41-08-252-85. Quality Management of Analytical Work, Standard Samples of the Enterprise. Development, Certification and Approval, 41 [in Russian].

17. TPI 1.1.412.YaF.1973 NSAM 412-YaF (1973) [in Russian].

18. L.N.Yakovleva, Ukr. Metrolog. J., 2, 250 (1999).

19. DTEU 12-01-97, State Primary Standard of Unit of Volume Activity of Radon-222 [in Ukrainian].

20. DSTU 3536-97, Metrology. State Verification Scheme for Measurements of Radon-222 Volumetric Activity. Gosstandart of Ukraine, Kiev (1997) [in Ukrainian].

21. DSTU 3232-95, Standard Samples. Main Provisions, Procedure for Development, Certification, Approval, Registration and Application, State Standard of Ukraine, Kyiv (1996) [in Russian].

22. M.I.Kravchenko, V.O.Katshey, V.V.Sklyarov, Creation of a State Special Standard for the Unit of Volumetric Activity of Radon-222, Final R \& D report, NNVO "Metrology", Kharkiv (1996) [in Ukrainian].

23. L.M.Solodovnikova, Materials of the National Forum, Lugansk, October 24-25, 2013, Center for Environmental Education and Information, Kiev, Ukraine (2013) .

24. L.N.Yakovleva, V.V.Baliberdin, V.V.Solovey, Intern. Sci. Techn. Conf., Scientific Works, Kharkiv (2004) [in Ukrainian].

25. G.D.Kovalenko, M.V.Babayev, L.N.Solodovnikova, Report about R\&N No. 1923/1.8/3853 UkrNIIEP, Kharkiv (2009) [in Russian].

26. V.L.Chesnov, K.Yu.Soroka, Bull. Pridniprovsk State Academy of Civil Engineering and Architecture, No.8, 149 (2010).

27. Norms of Radiation Safety of Ukraine (NRBU-97), State Hygiene Norms DHA 6.6.1.-6.5.001-98, Department of Polygraphy of the Ukrainian Center for State Surveillance of the Ministry of Health of Ukraine, Kyiv (1998) [in Ukrainian]. 